\title{
Reception and the Textuality of History: Ramus and Kepler on Proclus' History and Philosophy of Geometry
}

\author{
Guy Claessens
}

\section{Petrus Ramus: History as Forgetting}

In the Prooemium mathematicum of 1567, Petrus Ramus' opinion about Proclus is, for the most part, positive: the Neoplatonist may not have been a great logician (licet logica leviter instructus), he was undoubtedly an excellent mathematician (attamen eximius mathematicus fuit), whose commentary on Euclid is definitely worth the effort of reading. ${ }^{2}$ Ramus' initial judgment rapidly changes when he broaches the subject of the so-called Platonic polyhedra (cf. infra). After all, apart from the educational value of the Elements - as an all-embracing starter pack for both teachers and students - Proclus had also mentioned a second, more important goal of geometry:

But Proclus located the other exceptional and admirable goal in the knowledge of the five cosmic figures [...], as if the structure of such figures, their description and mutual comparison are of so great importance that the whole use, i.e. the goal, of mathematics will be achieved when you have mastered those very few things [...]. But that sacred goal of geometry was fiercely criticized and refuted by Aristotle in chapter 8, book 3 of On the Heavens, and Proclus himself had philosophized more seriously before, when he explained that the mathematical arts were invented for the sake of common usefulness. ${ }^{3}$

1 I would like sincerely to thank Demmy Verbeke as well as this volume's anonymous referees for their helpful remarks following their reading of earlier versions of this article.

2 Ramus, Prooem. math. 154.

3 Ramus, Prooem. math. 189-91: "Alterum vero mathematicae finem singularem Proclus \& admirabilem [...] constituit in quinque mundanarum figurarum cognitione [...] tanquam talium figurarum constitutio, adscriptio inter se \& comparatio tantifuerit, ut mathematicae totius utilitas, id est finis, constiterit, si haec paucula teneas. [...] Verum sacer ille geometriae finis ab Aristotele 8. cap. 3. lib. de caelo vehementer exagitatus \& labefactatus est, longeque gravius Proclus ipse est antea philosophatus, cum mathematicas artes popularis utilitatis causa repertas esse docuit." The passage of On the Heavens referred to by Ramus is Aristotle, Cael. 306b2ff.

(C) GUY CLAESSENS, 2015 | DOI 10.1163/9789004270848_016

This is an open access chapter distributed under the terms of the Creative Commons AttributionNoncommercial 3.o Unported (CC-BY-NC 3.o) License. 
For the present discussion, the most important element of this passage is Ramus' identification of the use (utilitas) and the goal (finis) of geometry. Exactly because of this assimilation the possibility of a sacred (sacer) and metaphysical geometry is dismissed. For Ramus, only the prospect of a practical geometry as an ars bene metiendi ${ }^{4}$ remains or, as strikingly put by Walter Ong: "one studies geometry 'to measure well,' not to understand mathematics [...]." "5

The passage of Proclus' Commentary on the First Book of Euclid's Elements referred to by Ramus at the end of the above quote is situated at the beginning of the famous history of geometry reported in the second prologue $(I E, 64$, $7-68,23)$ :

But limiting our investigation to the origin of the arts and sciences in the present age, we say, as have most writers of history, that geometry was first discovered among the Egyptians and originated in the remeasuring of their lands. This was necessary for them because the Nile overflows and obliterates the boundary lines between their properties. It is not surprising that the discovery of this and the other sciences had its origin in necessity, since everything in the world of generation proceeds from imperfection to perfection. ${ }^{6}$

According to Proclus, the reason for geometry's birth "out of necessity" ( $\dot{\alpha} \pi \dot{\partial} \tau \hat{\zeta}$

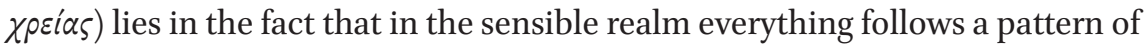
increasing perfection: from sense-perception ( $\alpha i \sigma \vartheta \eta \sigma \zeta \zeta$ ) over discursive reason-

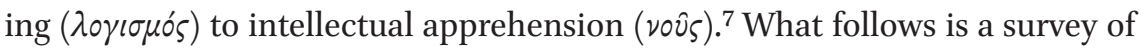
the history of geometry as evolving from initial materiality to pure intellectuality, ${ }^{8}$ all brought together around Plato and his followers. ${ }^{9}$ The writ-

Ramus, Geometria, I, 1 in Arithmeticae libri duo et geometriae libri septem et viginti (1569). Ong (1958) 179 .

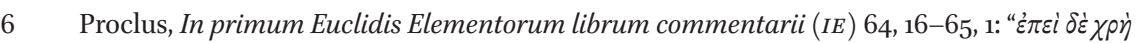

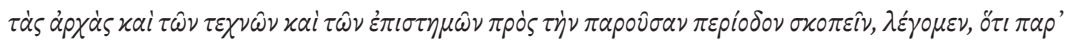

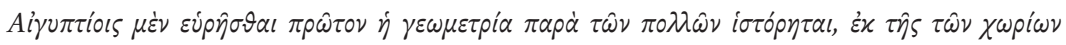

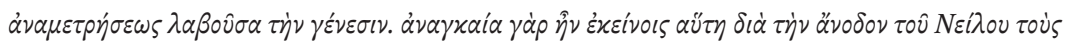

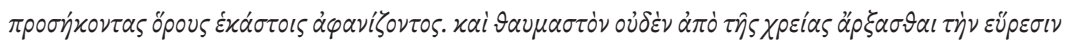

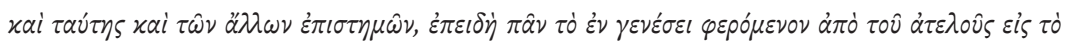

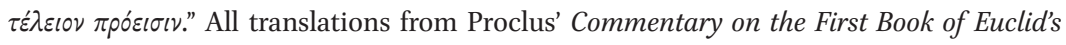
Elements in this article are taken from Morrow (1992) with some modifications.

7 Proclus, IE 64, 23-65, 3.

$8 \quad$ Goulding (2006) 79.

$9 \quad$ Mueller in Morrow (1992) xxix. 
ings of Euclid - a Platonist according to Proclus ${ }^{10}$ - are the ultimate pinnacle and synthesis of this historical awakening:

Not long after these men came Euclid, who brought together the Elements, systematizing many of the theorems of Eudoxus, perfecting many of those of Theaetetus, and putting in irrefutable demonstrable form propositions that had been rather loosely established by his predecessors. ${ }^{11}$

In the foreword of his Euclid-edition of $1544,{ }^{12}$ Ramus agrees with Proclus to the extent that he believes the history of mathematics to be an evolutionary process. Strangely enough this agreement with Proclus goes hand in hand with a new and original interpretation of the etymology suggested by the Neoplatonist for the word " $\mu \alpha \vartheta \eta \alpha \tau i x \eta$." Proclus writes the following:

As for the name itself that is applied to mathematics and mathematical studies, from what source could we say the ancients got it for these sciences, and what relevant meaning could it have? In my opinion, such a designation for the science of dianoetic reasoning did not come about by accident, as most names do. According to the tradition, the Pythagoreans recognized that everything we call learning is remembering, not something placed in the mind from without [...]. This, then, is what learning $(\mu \alpha \dot{\imath} \eta \sigma \varsigma)$ is, recollection of the eternal ideas in the soul; and this is why the study that especially brings us the recollection of these ideas is called the science concerned with learning $\left(\mu \alpha \vartheta \eta \mu \tau i x \eta^{\prime}\right){ }^{13}$

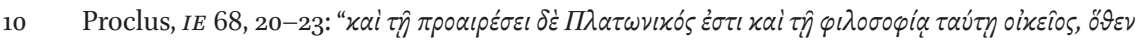

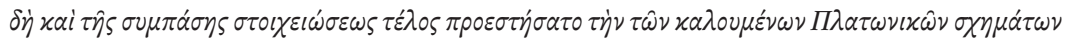
$\sigma \dot{\sigma \tau} \tau \sigma \tau \nu . "$ / "Euclid belonged to the persuasion of Plato and was at home in this philosophy; and this is why he thought the goal of the Elements as a whole to be the construction of the so-called Platonic figures."

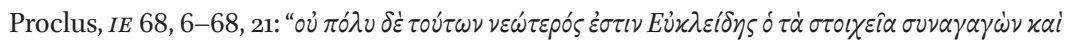

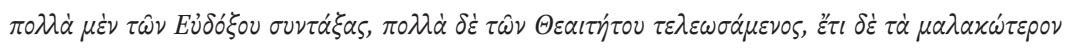

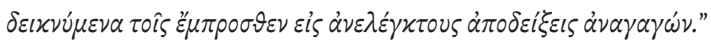

The foreword is included in Ramus' Collectaneae praefationes (1599) 119-21.

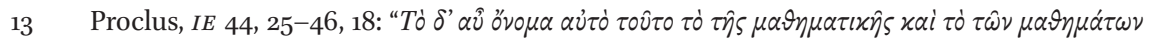

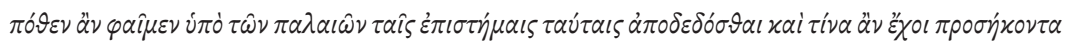

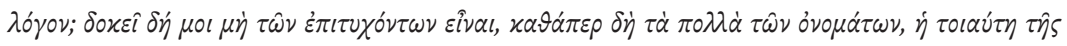

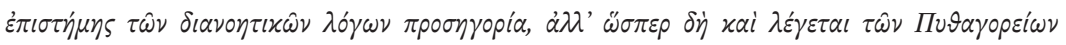

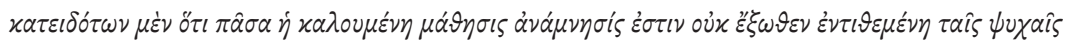


Ramus endorses the viewpoint that $\mu \dot{\alpha} \vartheta \eta \sigma \iota \varsigma$ and $\alpha \nu \alpha \dot{\mu} \nu \eta \sigma \varsigma$ should be connected, but he differs from Proclus in two important ways. ${ }^{14}$ Firstly, he transfers the notion of mathematics as a process of reminiscence from the level of the individual to that of a collective history. Secondly, according to Ramus, this mathematical learning does not involve the remembering of innate concepts, but of mathematical practice instead:

Obviously, to construct the building of this mathematical recollection, one has to appeal to many craftsmen and many architects, since not only would neither a single man nor a single generation be sufficient to create the science of such a noble and extraordinary discipline, but hardly many thousands of men and generations. ${ }^{15}$

Thirteen years later, in the Prooemium mathematicum, Ramus tells a radically different story and seems to get rid of the evolutionary aspect as well. According to Robert Goulding, ${ }^{16}$ this change of heart can be explained by the observation that sixteenth-century mathematics was far from the natural and well organized science one would expect it to be at the end of a linear development that started thousands of years ago. Mathematics, instead, "turned out to be difficult."17 In order to grasp the significance of the words "natural" and "difficult" in Ramus' discourse, a brief outline of Ramus' philosophy of science is required.

The picture roughly looks as follows. ${ }^{18}$ Dialectics - and every other science - consists of three aspects: natura, doctrina and exercitatio. All of us are born with a natural disposition to reason dialectically. In this state of affairs we are dealing with natural and not scientifically-developed knowledge: people use logic in speaking and writing, even without formal training. This natural art has to be the starting-point for the development of a discipline (doctrina) based on the imitation of the appropriate exemplars (for instance, Cicero in

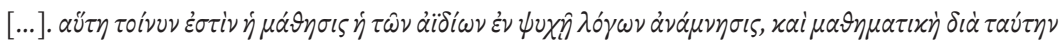

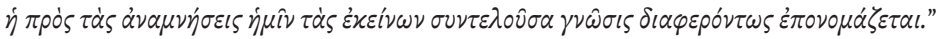

$14 \quad$ Goulding $(2006) 72$.

15 Ramus, Collectaneae praefationes 121: "videlicet huius mathematicae recordationis opus exaedificandum, tot fabros, tot architectos adhiberi oportuit, quia non modo non homo unus, aut aetas una: sed vix multa \& hominum, \& aetatum millia ad constituendam tam nobilis, atque praestantis doctrinae scientiam sufficerent."

16 Goulding (2006) 73-74.

$17 \quad$ Goulding $(2006) 74$.

18 This brief outline is based on Ong (1958) 175ff., Skalnik (2002) 48ff. and Goulding (2006) $64 \mathrm{ff}$. 
rhetoric). This formal organisation is completely focused on training (exercitatio), and its ultimate goal is practical use. It goes without saying that this doctrina is not a mere copy of natural dialectics, since it is the art of reasoning well (bene): "Ramus' subsequent restoration of the Ciceronian bene, to make dialectic mean 'the art of discoursing well' points up to the difference between the 'art' of dialectic and 'natural' dialectic. A person endowed with natural dialectic can discourse, but not so 'well' as he might."19 By means of articulation and training, the natural art has to become a second nature (habitus). Against this background Ramus' reform of logic becomes evident: the logic taught at the universities is in a sharp contrast with natural logic and has to be reorganised to regain its natural purity and practical use. ${ }^{20}$

Ramus' views on dialectics apply to mathematics as well. His experience and evaluation of contemporary mathematics as a difficult and unnatural science inevitably alter his ideas concerning the history of mathematics. Mathematics has been deprived of its practical origin and, one might say, has been denaturalised. Therefore, the model of a collective recollection should be abandoned. But where did it go wrong? According to Ramus, it is Plato who should be held responsible for this degeneration. In the Prooemium mathemat-

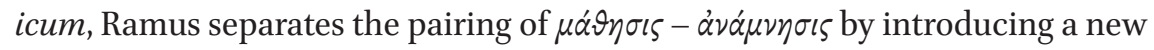
etymology for " $\mu \alpha \vartheta \eta \mu \alpha \tau i \eta$," based upon the meaning of $\mu \alpha \dot{\eta} \eta \sigma / \varsigma$ as "learning." What is more, Ramus gives an ingenious twist to the etymology suggested in his foreword to Euclid of 1544: instead of the original interpretation of the term recordatio as a collective remembering of mathematical practice, he now adheres to Proclus' reading, namely recordatio as an individual recollection of innate concepts. Once again - in an almost literal translation - Ramus refers to Proclus' account, albeit only to refute him:

He [i.e. Proclus] answers that this name is not given in a common manner, like others, but that is was given by the Pythagoreans based on the argument of the recollection, namely that all learning is remembering [...]. Until now, that recollection has not been found in anyone so fertile, that by means of it one art has been discovered without industry and labour. In reality, that name was invented arbitrarily, and not because of an initial excellence, but because of a property: during many ages mathematics was the only discipline. ${ }^{21}$

\footnotetext{
$19 \quad$ Ong (1958) 179.

$20 \quad$ Goulding (2006) 65.

$21 \quad$ Ramus, Prooem. math. 354-55: "Respondet non vulgo id nomen, ut caetera, factum esse, sed a Pythagoreis impositum e recordationis argumento, quod omnis quae dicitur disciplina,
} 
Is it not obvious then, says Ramus, from the examples of the diligence (industria) and effort (labor) of numerous mathematicians sketched in the first book of the Prooemium, that mathematics came into being by means of sensory perception (a sensu), induction (inductio) and experience (experientia)? Therefore, is this art not in origin strange and external (advena) instead of inborn (indigena) ${ }^{22}$

Yet, if the history of those mathematical acts cannot be read as a story of progress, how is it to be understood? Is a degenerative model a valid alternative? What is certain is that Ramus seems fully aware that his recollection model can only function as a prescriptive, theoretical program which is unable to cope with possible "abnormal" corruptions. From Ramus' viewpoint the main responsibility for the unnatural corruption that turned the history of mathematics into a false history lies with Plato. When Plato's students Archytas and Eudoxus vulgarized geometry by moving it from the domain of the soul and stressed its practical usefulness, their master's reaction sealed the fate of geometry:

But Plato, outraged because the noblest possession of philosophy was revealed and relinquished to the masses, banned both of them from his institute, as if they had betrayed the secret mysteries of philosophy. It goes without saying that I cannot approve of Plato's act. ${ }^{23}$

Put differently, it is Plato's choice to exclude "the masses" that has derailed the history of geometry. By turning geometry into an exclusive domain of philosophy, Plato withdrew it from everyday practical use. According to Ramus, the return of a natural geometry is only possible when the words usus and finis become synonyms again, and geometry returns to being the ars bene metiendi instead of a way to understand mathematics or philosophy.

recordatio est [...]. Recordatio ista adhuc in nemine tam felix inventa est, ut eius beneficio sine studio \& labore ars ulla perciperetur. Nomen vero ipsum pro arbitrio factum est, nec ulla quidem initio excellentia, sed proprietate: solae enim multis seculis artes mathematicae fuerunt."

22 Ramus, Prooem. math. 356-57.

23 Ramus, Prooem. math. 73: "Verum indignatus Plato quod nobilissimam philosophorum possessionem in vulgus indicarent ac publicarent, \& velut arcana philosophiae mysteria proderent, utrumque ab instituto deterruit. Quod factum Platonis equidem laudare non possum." 


\section{Johannes Kepler: History as Awakening}

In the prologue of the first book of the Harmonices mundi, published in Linz in 1619, Johannes Kepler directly challenges Ramus' interpretation of Proclus' commentary. ${ }^{24}$ What is at stake is the acknowledgement of the philosophical and theological bearing of geometry. In his critique of Ramus, Kepler shows how the philosophical relevance of geometry is reflected in the archetypical construction of the cosmos. According to Kepler, Ramus failed to understand the role played by the five Platonic solids in God's original design of the universe:

[...] and then, as he knew that Proclus was a member of the Pythagorean sect, he did not believe him when he asserted, which was quite true, that the ultimate aim of Euclid's work [...] was the five regular solids. ${ }^{25}$

The passage quoted in footnote 10 indeed asserts that, according to Proclus, Euclid belonged to the school of Plato and therefore believed the aim of the Elements to be the construction of the five Platonic solids. ${ }^{26}$ The five Platonic polyhedra (tetrahedron, cube, octahedron, dodecahedron, icosahedron) are the only possible regular polyhedra made up of congruent regular polygons. ${ }^{27}$ Their construction is described by Timaeus in Plato's eponymous dialogue, where four out of five regular solids are connected with the elements water, fire, air and earth. ${ }^{28}$ Although the alleged Pythagorean origin of the theory of the Platonic solids - and its association with the elements - is now a much debated topic, ${ }^{29}$ Kepler considered it to be a genuinely Pythagorean invention. ${ }^{30}$ Two compatible reasons, I think, can be given. Firstly, Plato sets out the

24 Kepler, Hм 17: "Lectus est liber Procli Petro Ramo, sed quoad nucleum attinet philosophiae, pariter cum decimo Euclidis contemptus et abjectus." / "The book of Proclus was read by Petrus Ramus, but as far as the core of philosophy is concerned, it was despised and rejected equally with the tenth Book of Euclid." All translations from Kepler's Harmonices mundi (нм) in this article are taken from Aiton (1997) with some modifications.

25 Kepler, $H$ M 17: "[...] deinde cum sciret Proclum fuisse Pythagoricae sectae, non credidit ei affirmanti, quod erat verissimum, sc. Euclidei operis ultimum finem [...] esse quinque corpora regularia."

26 See footnote 10.

$27 \quad$ See Field (1988) $6 \mathrm{ff}$.

28 Plato, Ti. 55d6-56c7. Tetrahedron - fire; cube - earth; octahedron - air and icosahedron - water. Timaeus does not explain how the Demiurge used the dodecahedron.

29 See Heath (1960) 158-62.

$30 \quad$ Kepler, HM 17: "[...] pythagoricam philosophiam circa elementorum proprietates ex quinque corporas deductas." / "[...] the Pythagorean philosophy on the properties of the elements 
theory as recounted by the Pythagorean Timaeus, ${ }^{31}$ a fact explicitly underlined by Kepler. ${ }^{32}$ Secondly, it is likely that Kepler relied on the following testimony from Proclus' commentary:

Following upon these men, Pythagoras transformed mathematical philosophy into a scheme of liberal education, surveying its principles from the highest downwards and investigating its theorems in an immaterial and intellectual manner. It was he who discovered the doctrine of proportionals and the structure of the cosmic figures. ${ }^{33}$

At first sight it may seem strange that Kepler even goes one step further, namely by counting Proclus among the members of the Pythagorean sect (pythagorica secta). However, from Kepler's perspective, the evidence is overwhelming: like the Pythagoreans, Proclus states that numbers reflect the properties of the highest beings; ${ }^{34}$ like the Pythagorean Timaeus, Proclus mentions the world soul governing the stars; ${ }^{35}$ Proclus' hymn written to the Sun is clearly inspired by the same school. ${ }^{36}$

as deduced from the five solids." Ibidem 80: "Haec sunt illa corpora quinque, quae figuras mundanas appellare sunt soliti pythagorei, Plato, et Euclidis commentator Proclus." / "These are the five bodies which the Pythagoreans and Plato, and Proclus, the commentator on Euclid, were accustomed to call the world figures."

$31 \quad$ Heath (1960) $15^{8 .}$

32 Kepler, Hм 265: "[...] Timaeus Locrensis ex pythagoricis placitis apud Platonem defendit." / "[...] defended from the Pythagorean beliefs by Timaeus of Locri in Plato." Cf. ibidem 221:

"In Timaeo, qui est citra omnem dubitationis aleam, commentarius quidam in primum caput Geneseos seu lib. I. Mosis, transformans illum in philosophiam pythagoricam." / "In the Timaeus, which is beyond all hazard of doubt a kind of commentary on the first chapter of Genesis, or the first book of Moses, converting it to the Pythagorean philosophy" (my emphasis).

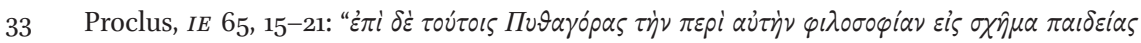

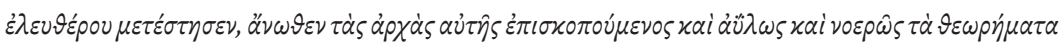

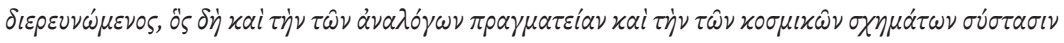

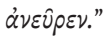

34 Kepler, HM 99: "Et Proclus pythagoricus theologiam in numerorum contemplatione collocet." / "And Proclus the Pythagorean locates his theology in the contemplation of numbers." See Proclus, IE 22, 6-8.

35 Kepler, нм 265: "Esse aliquam totius universi Animam, praefectam motibus astrorum [...] Proclus vero [...] stabilivit." / "The view that there is some soul of the whole universe, directing the motions of the stars [...] is in fact confirmed by Proclus in various places $[\ldots] . "$

36 Kepler, нм 365: "Quo exordio simul indicat, quid Pythagorei sub ignis vocabulo intellexerint (ut mirum sit, discipulum a magistris in centri loco, quod ipsi soli dabant, dissentire." / "By 
Contrary to what one would expect, Kepler is not interested in the connection between the polyhedra and the four (or five) elements, ${ }^{37}$ but in their role in God's original design of the cosmos. Twenty-two years before, in the Mysterium cosmographicum (1596), Kepler "discovered" the unique relationship between the polyhedra and the construction of the universe. ${ }^{38}$ Firstly, the Creator had relied on the cosmic figures for the respective distance ratios between the spheres of the various planets (e.g. the tetrahedron fits proportionally between the orbits of Jupiter and Mars). Although the discovery of the elliptical orbit of the planets between the publishing of the Mysterium cosmographicum and the completion of the Harmonices mundi has severe consequences for this model as well, Kepler stuck to the idea that the distance between the orbits of two planets could be traced back to the ratio between the circumscribed and inscribed sphere of one of the five solids. ${ }^{39}$ Secondly, according to Kepler, for the creation of the number of planets God had started from the five cosmic polyhedra. Since the distance between the orbits of two planets can be expressed by means of a regular polyhedron and since only five regular polyhedra can be constructed, the number of planets amounts to six. ${ }^{40}$

From the above, it is clear that Kepler extracts - in his opinion - a PlatonicPythagorean element, namely the construction of the five polyhedra, from its original connection with the cosmic elements and applies it to God's blueprint of the universe. The legitimacy of this transplantation is guaranteed by Kepler himself. ${ }^{41}$ The link between the polyhedra and the elements is valid as a plausible analogy (analogia plausibilis) from the perspective of the Creation as an act of God in the guise of geometrician (mundum a Deo creatum esse, in

this beginning he indicates what the Pythagoreans understood by the word "fire," so that it is remarkable that the disciple disagreed with the masters on the position of the center, which they gave to the Sun itself." (my emphasis) Cf. ibidem 367: "[...] ex hoc Pythagorae cratere, quem Proclus in ipso statim primo versu hymni propinat." / "[...] from this cup of Pythagoras, which Proclus pledges straight away in the very first verse of his Hymn."

The association of the elements with the Platonic solids became widespread in Western iconography and is also found in Kepler's HM. See Stephenson (1994) 20.

$38 \quad$ Kepler, $H$ M 298.

39 Field (1988) 93ff. Cf. Kepler, нм 299.

$40 \quad$ Kepler, нм 298: "Tertio repetat lector ex Mysterio meo Cosmographico, quod edidi ante 22. annos: numerum planetarum seu curriculorum circa solem, desumptum esse a sapientissimo conditore ex quinque figuris regularibus solidis [...]." / "Third, the reader should remember what I published in The Secret of the Universe, 22 years ago, that the number of the planets, or of courses round the Sun, was taken by the most wise Creator from the five regular solid figures [...]."

$41 \quad$ Kepler, $H м 81$. 
pondere mensura et numero $).{ }^{42}$ But when it comes down to the validity of this analogy an sich (tamen sic in specie informata), it is not a matter of necessary truth (nulla necessitate continetur). The acceptability and necessity of the analogy are for Kepler clearly distinct criteria. It is interesting to see how Kepler leaves the possibility open that for the Pythagoreans as well, these criteria were dissimilar:

If the Pythagoreans held onto this theory, I do not blame Ramus, or Aristotle, for rejecting this disputed analogy. But twenty-four years ago I discovered a very different relation between these five figures and the fabric of the world. I said in the introduction to book 1 that I thought it likely that even some of the ancients had been of this same opinion, but had kept it secret, in the manner of their sect. ${ }^{43}$

In the following, Kepler gives the example of the Pythagorean Aristarchus of Samos who made an allusion to the interposition of the polyhedra by describing how the cosmos comprises six spheres around the sun which are separated from each other by large and unequal intervals (magnisque et inter se inaequalibus intervallis dirempta). In other words: even in this question Kepler is in the possession of the hermeneutical key by means of which the truth that was concealed by the Pythagoreans in the capacity of a plausible analogy can be deciphered. When we return to Kepler's quarrel with Ramus, a similar argument is found:

What if the Pythagoreans put forward the same teaching as I do, and hid their doctrine by wrapping it up in words? [...] Therefore that in the secret of the Pythagoreans on this basis the five figures were distributed not among the elements, as Aristotle believed, but among the planets themselves is very strongly confirmed by the fact that Proclus tells us that the aim of geometry is to tell how the heaven has received appropriate figures for definite parts of itself.44

$42 \quad$ Book of Wisdom 11.

43 Kepler, $H M$ 81: "Quod si hic substiterunt Pythagorei, non reprehendo in hac parte Ramum, non Aristotelem, quod hanc analogiam disputationibus convulsam rejecerunt. At ego ante annos viginti quatuor, longe aliter haec quinque corpora in fabrica Mundi indagavi; dixique in praeambulo libri I. mihi videri consentaneum, eandem doctrinam etiam veterum fuisse, sed occultatam more sectae."

44 Kepler, HM 17-18: "Quid si Pythagorici hoc idem docuerunt, quod ego, sententiam involucris verborum texerunt? [...] Quod igitur in mysteriis Pythagoreorum hoc pacto quinque figurae distributae fuerint non inter elementa, ut Aristoteles credidit, sed inter ipsos planetas; illud 
I pay close attention to Kepler's and Ramus' differing views on the role of the five Platonic solids, because in Kepler's opinion - as in my own - this particular point indicates the essential difference between his reading of Proclus (and Euclid) and that of Ramus and his followers. After his outburst against Ramus Kepler targets one of Ramus' students by the name of Snellius. ${ }^{45}$ The fact that Kepler explicitly refers to Snellius as a follower of Ramus proves that we are not dealing with a simple ad hominem, but with a vicious attack on Ramism in general:

Consider the most ingenious of today's geometers, Snellius, clearly a supporter of Ramus [...]. First he says, "That division of the inexpressibles into thirteen kinds is useless for application." I concede that, if he is to recognize no application unless it is in everyday life [...]. But why does he not follow Proclus, whom he mentions, and who recognizes that there is some greater good in geometry than those of the arts which are necessary for living? ${ }^{46}$

The core of Kepler's critique amounts to the following: a Ramist is only interested in the direct usefulness (usus in vita communi and usus ad vitam) of mathematics for daily life and fails to appreciate the philosophical value at stake.

Kepler's reading of Proclus differs fundamentally from Ramus' utilitarian approach. ${ }^{47}$ In the introduction of the first book of the Harmonices mundi Kepler reports how Proclus was the only one in Antiquity to philosophically interpret Euclid's Elements:

In fact not even among the ancients is anyone found who has intimated that he knew exactly these specific distinguishing features of geometrical objects, except for Euclid and his commentator Proclus. [...] Proclus Diadochus in the four books which he published on the first book of

vel maxime confirmat, quod Proclus finem geometriae inter caeteros hunc tradit, quod doceat, quo modo figuras convenientes coelum certis sui partibus acceperit."

45 Willebrord Snellius (1580-1626) was a Dutch mathematician whom Kepler knew personally. See Aiton (1997) 88.

46 Kepler, HM 18: "Ecce sollertissimum geometrarum hodiernorum Snellium, plane suffragantem Ramo [...]. Primum ait, ad usum inutilem esse divisionem illam ineffabilium in tredecim species. Concedo, si nullum ille usum agnoscat, nisi in vita communi [...]. At cur non Proclum sequitur, quem allegat, qui agnoscit aliquod maius geometriae bonum, quam sunt artes ad vitam necessariae?"

On Proclus and Kepler as exegetes, also see Claessens (2011) 183-86. 
Euclid explicitly played the part of a theoretical philosopher dealing with a mathematical subject. ${ }^{48}$

From Kepler's perspective, Proclus' text becomes fundamental and even indispensable for a correct understanding of geometry's philosophical bearing: "But there is no need for arguments: Proclus' whole book should be read." ${ }^{\prime 9}$ What is more, the hermeneutical key needed is similar to that of the Pythagorean corpus. Proclus does not state this doctrine openly and conspicuously (non in aperto et conspicuo ponit), but his eloquence flows fully (pleno velut alveo) and is wrapped in obscure Platonic terminology. ${ }^{50}$ Only Kepler is able to penetrate into such mysteries (ad tam recondita penetrare).

Kepler thus asserts that Euclid's text is in permanent need of a commentator providing the philosophical framework in which the text should function. ${ }^{51}$ Proclus' Commentary on the First Book of Euclid's Elements is a decisive moment in the reception of geometry as philosophy. It is not surprising then, that Kepler understands the poor geometrical knowledge of his contemporaries as a symptom of the oblivion into which Proclus' text has fallen. Obviously, this problem can be solved by bringing renewed attention to Proclus' text, with Kepler as the exegete par excellence. After all, only Proclus has witnessed the same Christian truth that Kepler now tries to explain. ${ }^{52}$

\section{Conclusion}

For both Kepler and Ramus any comparison between sixteenth- or seventeenth-century Europe and Antiquity concerning mathematical thinking points in one direction: that of the past. Somewhere on the road "truth" has been lost. Both thinkers see it as their task to rectify this loss by reproducing an original moment of the past, prior to this fall. The way in which this return has to be made and the precise moment that should be reproduced, however, is for both men completely different. Ramus wants to return to a moment before

48 Kepler, нм 15: "Adeoque ne ex veteribus quidem, qui has specificas rerum geometricarum differentias se exacte cognovisse significaverit, praeter Euclidem ejusque commentatorem Proclum, quisquam occurrit. [...] Proclus Diadochus, libris quatuor in primum Euclidis editis, Philosophum Theoreticum in mathematico subjecto ex professo egit."

49 Kepler, нм 16: "Sed non est opus argumentatione, legatur totus liber Procli."

50 Kepler, $н$ м 16.

$51 \quad$ See Claessens (2011) 184.

$5^{2} \quad$ Kepler, ${ }^{2}$ 364. According to Kepler the Christian foundation of that truth has always already been present in Proclus' work. See Martens (2000) 34 . 
and outside of the textual history and tradition: a collective primordial state where nature rules. According to Ramus, truth coincides with an initial, natural disposition, and a return to this disposition is therefore a return to the past. It is history, in all its appearances, that stands between us and our nature: the evolution of education, the oblivion of usefulness, the arrogant choice that alienated man from nature, et cetera. The only solution available is a methodical reform, modelled on our own nature instead of external authorities. In his Dialecticae institutiones (1543) Ramus writes that we would do better to obtain advice from unschooled workers than from scientists. From the logical - and unaffected - mind of the former, the image of our nature will reflect as in a mirror (ex eorum ingeniis veluti speculis imago naturae resultabit). ${ }^{53}$

Kepler, on the other hand, chooses an irreproducible moment within history. It is exactly history, that spiritual awakening situated in time, that forms the necessary condition for revealing our essence. According to Kepler, the actual situation should be ascribed to a crack in the tradition. The only way to restore this gap is linking up with tradition. Firstly, by bringing Proclus' commentary to the attention of his contemporaries; secondly, by completing the project initiated by the Neoplatonist. Consequently, the moment of the past to which Kepler wishes to return is by no means a democratic, collective primordial state. On the contrary, Kepler's paradise lost is a highly individual and privileged testimony that originated within a history and was crystallized in this specific text. Like Proclus, Kepler is a witness and both testimonials function within a dialogue of mutual affirmation. The text as a historical momentum gives access to truth and Kepler holds the hermeneutical key.

In Kepler's account of the history of geometry as a process of spiritual awakening the $\dot{\alpha} \rho x \dot{\eta}$ of geometry coincides with the $\dot{\alpha} p \times \dot{y}$ of philosophy, namely the textual history of Platonism. In other words, history is originally an evolution towards the text. On the contrary, Ramus' verdict of Platonism shows a history of alienation: not a history of texts, but an anti-textual history of people and acts. Geometry's ápxý precedes the text of philosophy, its goal is a-textual. Kepler praises Antiquity as the place of an historical and authentic momentum, while Ramus considers this textualization precisely as the alienation from a reproducible moment where man coincides with his materiality. Both interpretations thus reveal an explicitly different contact with Antiquity, which brings about a crucial shift in the meaning of the term reception. For Kepler, receiving Antiquity is and should be a textual phenomenon: it is the bridging of a gap and the restoration and fulfilment of a spiritual-textual tradition. From

53 This example is given by Goulding (2006) 65 and stems from Ramus, Dialect. Instit. f. 6. 
Ramus' perspective, receiving Antiquity can only be useful as an a-textual and material event, i.e. as the remembering of mathematical practice.

\section{Bibliography}

Aiton, E. et alii, trans., The Harmony of the World (Philadelphia, 1997).

Claessens, G., "Imagination as Self-knowledge: Kepler on Proclus' Commentary on the First Book of Euclid's Elements," in Early Science and Medicine 16 (2011), pp. 179-99.

Field, J.V., Kepler's Geometrical Cosmology (Chicago, 1988).

Goulding, R., "Method and Mathematics: Peter Ramus's Histories of the Sciences," in Journal of the History of Ideas 67/1 (2006), pp. 63-85.

Heath, T., A history of Greek Mathematics. Volume I. From Thales to Euclid(London, 1960). Martens, R., Kepler's Philosophy and the New Astronomy (Princeton, 2000).

Morrow, G., trans., Proclus. A Commentary to the First Book of Euclid's Elements. With a New Foreword by Ian Mueller (Princeton, 1992).

Ong, W.J., Ramus. Method and the Decay of Dialogue (Cambridge, Mass., 1958).

Skalnik, J.V., Ramus and Reform. University and Church at the End of the Renaissance (Kirksville, 2002).

Stephenson, B., Kepler's Physical Astronomy (Princeton, 1994). 